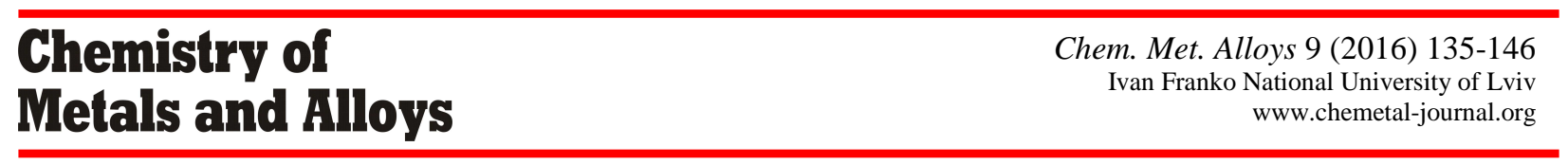

\title{
Formation and stability of ternary phases in the Ho-Ag-Sn and Tm-Ag-Sn metallic systems
}

\author{
L. ROMAKA ${ }^{1}$, I. ROMANIV ${ }^{1}$, V.V. ROMAKA ${ }^{2}$, A. HORYN ${ }^{1}$, Yu. STADNYK ${ }^{1}$ \\ ${ }^{1}$ Department of Inorganic Chemistry, Ivan Franko National University of Lviv, \\ Kyryla i Mefodiya St. 6, 79005 Lviv, Ukraine \\ ${ }^{2}$ Department of Materials Engineering and Applied Physics, Lviv Polytechnic National University, \\ Ustyyanovycha St. 5, 79013 Lviv, Ukraine \\ * Corresponding author. E-mail: romakal@lnu.edu.ua
}

Received October 19, 2016; accepted December 28, 2016; available on-line August 14, 2017

\begin{abstract}
The isothermal sections of the phase diagram of the Ho-Ag-Sn ternary system at $673 \mathrm{~K}$ and $873 \mathrm{~K}$ were constructed in the whole concentration range using X-ray diffraction and EPM analyses. The interaction between the elements results in the formation of three ternary compounds at $673 \mathrm{~K}$ : HoAgSn (LiGaGe-type, space group $\left.P 6_{3} m c, a=0.4667(1), c=0.7313(2) \mathrm{nm}\right), \mathrm{Ho}_{3} \mathrm{Ag}_{4} \mathrm{Sn}_{4}\left(\mathrm{Gd}_{3} \mathrm{Cu}_{4} \mathrm{Ge}_{4}\right.$-type, space group Immm, $a=0.4519(2), \quad b=0.7280(3), \quad c=1.5091(3) \mathrm{nm})$, and HoAgSn ${ }_{2} \quad\left(\mathrm{Cu}_{3} \mathrm{Au}-\mathrm{type}\right.$, space group Pm-3m, $a=0.4525(2) \mathrm{nm})$. At $873 \mathrm{~K}$ two ternary compounds (HoAgSn, LiGaGe-type and HoAgSn ${ }_{2}, \mathrm{Cu}_{3} \mathrm{Au}$-type) were found. Three ternary compounds exist in the Tm-Ag-Sn system at $873 \mathrm{~K}$ : TmAgSn (ZrNiAl-type, space group $P-62 m, \quad a=0.72635(9), \quad c=0.4435(1) \mathrm{nm}), \quad \mathrm{Tm}(\mathrm{Ag}, \mathrm{Sn})_{2} \quad\left(\mathrm{CaIn}_{2}\right.$-type, space group $P 6_{3} / \mathrm{mmc}$, $a=0.46534(2), c=0.72649(4) \mathrm{nm})$ and $\mathrm{TmAgSn}_{2}\left(\mathrm{Cu}_{3} \mathrm{Au}-\mathrm{type}\right.$, space group $\left.P m-3 m, a=0.45033(2) \mathrm{nm}\right)$. DSC/DTA analyses showed a limited stability range for $\mathrm{Ho}_{3} \mathrm{Ag}_{4} \mathrm{Sn}_{4}$ and the existence of a phase transition for

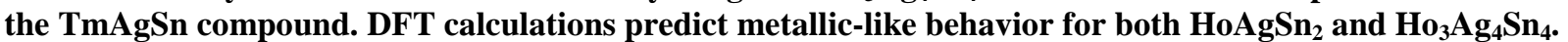

Intermetallics / Electronic structure / Diffraction / Differential scanning calorimetry

\section{Introduction}

The experimental investigation of phase diagrams of metallic systems is a fundamental step to determine the peculiarity of formation of the intermediate phases, their composition and stability, homogeneity range, and structural characteristics. The ternary systems with silver, tin and a light rare earth $(R=\mathrm{La}$, $\mathrm{Ce}, \mathrm{Pr}$ ) [1-3] are characterized by the formation of three intermediate phases, i.e. RAgSn (LiGaGe-type), $R_{3} \mathrm{Ag}_{4} \mathrm{Sn}_{4}\left(\mathrm{Gd}_{3} \mathrm{Cu}_{4} \mathrm{Ge}_{4}\right.$-type $)$, and $R_{5} \mathrm{AgSn}_{3}\left(\mathrm{Hf}_{5} \mathrm{Sn}_{3} \mathrm{Cu}\right.$ type), while with $\mathrm{Nd}$ and $\mathrm{Sm}$ only $\mathrm{RAgSn}$ and $R_{3} \mathrm{Ag}_{4} \mathrm{Sn}_{4}$ compounds were found [4,5]. The EuAgSn stannide with divalent state of europium adopts an orthorhombic $\mathrm{KHg}_{2}$-type structure [6]. The $R-\mathrm{Ag}-\mathrm{Sn}$ systems with a heavy rare earth are characterized by the formation of $R_{3} \mathrm{Ag}_{4} \mathrm{Sn}_{4}$ stannides ( $R=\mathrm{Y}, \mathrm{Gd}-\mathrm{Ho}$ ) crystallizing in the $\mathrm{Gd}_{3} \mathrm{Cu}_{4} \mathrm{Ge}_{4}$-type [7] and $R \mathrm{AgSn}_{2}$ stannides $(R=\mathrm{Y}, \mathrm{Gd}-\mathrm{Er})$ crystallizing in the cubic $\mathrm{Cu}_{3} \mathrm{Au}$-type [8]. Compared to the other $R-\mathrm{Ag}-\mathrm{Sn}$ systems the $\mathrm{Yb}-\mathrm{Ag}-\mathrm{Sn}$ system is more complicated and presents a higher number of intermediate phases [9], of which only the YbAgSn (CaLiSn-type) compound is similar to the other $R A g S n$ stannides. Equiatomic $R A g S n$ compounds exist with all the rare earths of the yttrium group, but depending on the valence state and size of the rare-earth element, they crystallize in different structure types: LiGaGe-type (Y, Gd-Er) [10,11], CaLiSn- and YbAgPb-types (Yb) [9,12], and ZrNiAl-type (Tm, Lu) [10]. The crystal structures of most of the $R \mathrm{AgSn}$ compounds were determined in the $\mathrm{CaIn}_{2}$ structure type (space group $\left.\mathrm{P6}_{3} / \mathrm{mmc}\right)$ with a mixture of elements $(0.5 \mathrm{Ag}+0.5 \mathrm{Sn})$ in the $4 f$ position [13]. Further investigations of the $R$ AgSn compounds ( $R=\mathrm{Ce}-\mathrm{Nd}$, Gd-Er) $[11,14]$ using single crystal $\mathrm{X}$-rays and neutron diffraction studies allowed describing the crystal structure more precisely in the LiGaGe-type (space group $P 6_{3} m c$, an ordered non-centrosymmetric variant of the $\mathrm{CaIn}_{2}$-type). Neutron diffraction studies of the RAgSn stannides indicated antiferromagnetic ordering for most of them $[11,15]$.

Previous studies of the $R A g S n$ stannides have shown the influence of temperature or pressure on their stability. A phase transition for the ErAgSn compound (ZrNiAl-type under high pressure and LiGaGe-type under ambient pressure) was reported in [16]. For the TmAgSn stannide the authors indicated that the high-temperature modification (LiGaGe-type) transforms into the low-temperature form ( $\mathrm{ZrNiAl}$ - 
type) upon annealing at $970 \mathrm{~K}$ for two days. However, for the HoAgSn, DyAgSn, and YbAgSn stannides no phase transition from the LiGaGe- to ZrNiAl-type was found under high-pressure / high-temperature conditions [14]. An investigation of the $\mathrm{Gd}-\mathrm{Ag}-\mathrm{Sn}$ system at $670 \mathrm{~K}$ and $870 \mathrm{~K}$ indicated an influence of the temperature on the formation of the ternary phases with high Sn content [17].

In the present paper the results of X-ray diffraction and EPM analyses of the phase equilibria in the Ho-Ag-Sn and Tm-Ag-Sn systems, and the thermal stability of some intermediate phases, are reported. Taking into account the influence of temperature and pressure on the formation, stability, and structure of the intermediate phases in related $R-\mathrm{Sn}$ and $R-\mathrm{Ag}-\mathrm{Sn}$ systems, the Ho-Ag-Sn system was studied both at $673 \mathrm{~K}$ and $873 \mathrm{~K}$.

\section{Experimental details}

The samples were prepared by direct arc melting of the constituent elements (rare earths, purity $99.9 \mathrm{wt} \%$; silver, purity 99.99 wt.\%; and tin, purity 99.999 wt.\%) under a high-purity Ti-gettered argon atmosphere on a water-cooled copper crucible. The weight losses of the initial total mass were less than $1 \mathrm{wt} . \%$. Pieces of the as-cast buttons were separately annealed for one month at $673 \mathrm{~K}$ and $873 \mathrm{~K}$ (Ho-Ag-Sn alloys) and at $873 \mathrm{~K}$ (Tm-Ag-Sn alloys) in evacuated silica tubes and then water-quenched. Phase analysis was performed using X-ray powder diffraction (DRON4.0, $\mathrm{Fe} K_{\alpha}$ radiation). The observed diffraction intensities were compared with reference powder patterns of known binary and ternary phases. The compositions of the samples were examined by Scanning Electron Microscopy (SEM), using REMMA-102-02 and JEOL-840A scanning electron microscopes. Quantitative electron probe microanalysis (EPMA) of the phases was carried out using an energy-dispersive X-ray analyzer with the pure elements as standards (the acceleration voltage was $20 \mathrm{kV} ; K$ - and $L$-lines were used). Diffraction patterns for the crystal structure refinements were collected at room temperature using a STOE STADI P powder diffractometer $\left(\mathrm{Cu} K_{\alpha 1}\right.$ radiation, curved germanium (1 111 ) monochromator, 6-110.625 $2 \theta$ range with $0.015^{\circ}$ scan step and $450 \mathrm{~s}$ exposure time). The crystallographic parameters were calculated using the WinCSD program package [18]. Rietveld refinements were performed using the WinPLOTR program package [19].

DSC and DTA analyses were performed for the $\mathrm{Ho}_{3} \mathrm{Ag}_{4} \mathrm{Sn}_{4}$ (NETZSCH STA449C Jupiter device, argon atmosphere) and $\mathrm{TmAgSn}$ compounds (LINSEIS STA PT 1600 device, argon atmosphere). The $\mathrm{Ho}_{3} \mathrm{Ag}_{4} \mathrm{Sn}_{4}$ sample was heated up to $1073 \mathrm{~K}$, while the TmAgSn sample was heated up to $1223 \mathrm{~K}$, at a rate of $10 \mathrm{~K} / \mathrm{min}$. The weight losses during heating (TG) were negligible (less than $0.3 \%$ ).
The temperature dependence of the magnetic susceptibility $\chi(T)$ was measured using the Faraday balance technique in the temperature range $80-360 \mathrm{~K}$ and magnetic fields up to $0.1 \mathrm{~T}$.

DFT (Density Functional Theory) electronic structure calculations of the ternary compounds with experimentally determined structural parameters were performed using the Elk package [20] (an all-electron full-potential linearized augmented-plane wave code with GGA [21] exchange-correlation functional). The $\mathrm{DFT}+\mathrm{U}$ approximation with $U=6.0 \mathrm{eV}, \quad$ spin polarization, and spin-orbit coupling was used. The VESTA package [22] was used for data visualization.

\section{Results and discussion}

\subsection{The binary systems}

To check the literature data on the Ho-Sn, Tm-Sn, Ho-Ag, Tm-Ag, and Ag-Sn systems [23-25], all known binary compounds were synthesized and confirmed in the course of our investigation. In the Ho-Sn system the $\mathrm{Ho}_{2} \mathrm{Sn}_{5}\left(\mathrm{Er}_{2} \mathrm{Ge}_{5}\right.$-type $)$ and $\mathrm{HoSn}_{3}$ $\left(\mathrm{GdSn}_{2.75}\right.$-type) compounds were only observed at $673 \mathrm{~K}$ according to the studied Sn-rich part of the Ho-Sn phase diagram [25]. In the Tm-Ag binary system at the composition $\mathrm{Tm}_{20} \mathrm{Ag}_{80}$ the $\mathrm{Tm}_{14} \mathrm{Ag}_{51}$ binary with $\mathrm{Gd}_{14} \mathrm{Ag}_{51}$-type $(a=1.2477(6)$, $c=0.9179(5) \mathrm{nm})$ was identified under our conditions.

Crystallographic characteristics of the binary phases observed in the $\{\mathrm{Ho}, \mathrm{Tm}\}-\mathrm{Ag}, \mathrm{Ag}-\mathrm{Sn}$ and $\{\mathrm{Ho}, \mathrm{Tm}\}-\mathrm{Sn}$ systems under the conditions used in this work are listed in Table 1.

\subsection{Isothermal sections of the Ho-Ag-Sn system at $673 \mathrm{~K}$ and $873 \mathrm{~K}$}

The phase equilibria in the $\mathrm{Ho}-\mathrm{Ag}-\mathrm{Sn}$ system were investigated in the whole concentration range at $673 \mathrm{~K}$ and $873 \mathrm{~K}$ using X-ray diffraction and metallographic analyses of 8 binary and 32 ternary alloys, annealed separately at both temperatures. The isothermal sections of the Ho-Ag-Sn ternary system at the selected temperatures are presented in Figs. 1 and 2. Microphotographs of some of the alloys are shown in Fig. 3. In the Ho-Ag-Sn ternary system silver dissolves up to $\sim 10$ at. $\% \mathrm{Sn}$ and $\sim 0.5$ at. $\%$ Ho at $673 \mathrm{~K}$, and up to $\sim 11$ at. $\% \mathrm{Sn}$ and $\sim 1$ at. $\%$ Ho at $873 \mathrm{~K}$. At $873 \mathrm{~K}$ the Sn-rich part of the binary Ag-Sn system exists in the liquid state, which continues in the ternary field up to $\sim 5$ at. $\%$ Ho.

The phase relations in the $\mathrm{Ho}-\mathrm{Ag}-\mathrm{Sn}$ system at $673 \mathrm{~K}$ (see Fig. 1) are characterized by the formation of three ternary compounds: $\mathrm{HoAgSn}, \mathrm{Ho}_{3} \mathrm{Ag}_{4} \mathrm{Sn}_{4}$, and $\mathrm{HoAgSn}_{2}$, the crystallographic characteristics of which are listed in Table 2. According to the results of the XRD analysis of alloys along the isoconcentrate of 25 at.\% Ho a homogeneity region $\left(\mathrm{HoAg}_{1-0.48} \mathrm{Sn}_{2-2.52}\right)$ exists for the $\mathrm{HoAgSn}_{2}$ compound ( $a=0.4525(2)$ $0.4567(1) \mathrm{nm})$. The limiting compositions of the $\mathrm{HoAgSn}_{2}$ compound were confirmed by EPMA data. 
The samples of compositions $\mathrm{Ho}_{25} \mathrm{Ag}_{10} \mathrm{Sn}_{65}$ (Fig. 3a) and $\mathrm{Ho}_{25} \mathrm{Ag}_{30} \mathrm{Sn}_{45}$ (Fig. 3c) are located in three-phase regions, the $\mathrm{HoAgSn}_{2}$ compound is in equilibrium with the $\mathrm{Ag}_{3} \mathrm{Sn}$ and $\mathrm{Sn}$ phases, and $\mathrm{HoAgSn}$ and $\mathrm{Ho}_{3} \mathrm{Ag}_{4} \mathrm{Sn}_{4}$, respectively. No significant solubility of the third component in the binary phases was observed in the Ho-Ag-Sn system at $673 \mathrm{~K}$.

The phase analysis of the Ho-Ag-Sn samples annealed at $873 \mathrm{~K}$ showed the formation of two ternary stannides: $\mathrm{HoAgSn}$ and $\mathrm{HoAgSn}_{2}$ (see Fig. 2). According to the XRD analysis a homogeneity region of the $\mathrm{HoAgSn}_{2}$ compound (HoAg $\mathrm{H}_{1-0.44} \mathrm{Sn}_{2-2.56}$, $a=0.4523(1)-0.4571(1) \mathrm{nm}) \quad$ exists along the isoconcentrate of 25 at.\% Ho. The sample of composition $\mathrm{Ho}_{25} \mathrm{Ag}_{10} \mathrm{Sn}_{65}$ (Fig. 3b) is located in a three-phase region and the main phase $\mathrm{HoAgSn}_{2}$ is in equilibrium with $\mathrm{Ag}_{0.8} \mathrm{Sn}_{0.2}$ and $\mathrm{Sn}$ phases. The
$\mathrm{Ho}_{3} \mathrm{Ag}_{4} \mathrm{Sn}_{4}$ ternary compound was not observed at $873 \mathrm{~K}$. According to the X-ray diffraction and microprobe analyses, the corresponding sample belongs to a three-phase field and contains HoAgSn, $\mathrm{HoAgSn}$, and $\mathrm{Ag}_{0.8} \mathrm{Sn}_{0.2}$ phases. We checked the $\mathrm{Ho}_{3} \mathrm{Ag}_{4} \mathrm{Sn}_{4}$ compound using differential scanning calorimetric analysis and confirmed the limited temperature range for this phase. The DSC curve measured in the heating regime shows a thermal peak at about $850 \mathrm{~K}$ (Fig. 4), which can be associated with the decomposition of the $\mathrm{Ho}_{3} \mathrm{Ag}_{4} \mathrm{Sn}_{4}$ phase, confirming the results of the phase analysis of the corresponding sample at $873 \mathrm{~K}$. In the $\mathrm{Ho}-\mathrm{Ag}-\mathrm{Sn}$ system at $873 \mathrm{~K}$ solubility of the third component in the binary phases was not observed, except for the $\mathrm{HoAg}$ binary, where the solubility of $\mathrm{Sn}$ is up to 5 at. $\%\left(\mathrm{Ho}_{50} \mathrm{Ag}_{45} \mathrm{Sn}_{5}, a=0.3599(1) \mathrm{nm}\right)$.

Table 1 The binary phases relevant to the isothermal sections of the Ho-Ag-Sn and Tm-Ag-Sn systems.

\begin{tabular}{|c|c|c|c|c|c|c|}
\hline \multirow{2}{*}{ Phase } & \multirow{2}{*}{ Space group } & \multirow{2}{*}{ Structure type } & \multicolumn{3}{|c|}{ Lattice parameters, $\mathrm{nm}$} & \multirow{2}{*}{ Ref. } \\
\hline & & & $a$ & $b$ & $c$ & \\
\hline $\mathrm{HoSn}_{3}$ & Amm2 & $\mathrm{GdSn}_{2.75}$ & $\begin{array}{l}0.4328(3) \\
0.4335\end{array}$ & $\begin{array}{l}0.4369(4) \\
0.4373\end{array}$ & $\begin{array}{l}2.1754(8) \\
2.1757\end{array}$ & $\begin{array}{l}\text { This work } \\
{[25]}\end{array}$ \\
\hline $\mathrm{Ho}_{2} \mathrm{Sn}_{5}$ & Pmmn & $\mathrm{Er}_{2} \mathrm{Ge}_{5}$ & $\begin{array}{l}0.4305(1) \\
0.4307\end{array}$ & $\begin{array}{l}0.4385(5) \\
0.4391\end{array}$ & $\begin{array}{l}1.8903(1) \\
1.8928\end{array}$ & $\begin{array}{l}\text { This work } \\
{[25]}\end{array}$ \\
\hline $\mathrm{HoSn}_{2}$ & $\mathrm{Cmcm}$ & $\mathrm{ZrSi}_{2}$ & $\begin{array}{l}0.4381(3) \\
0.4377\end{array}$ & $\begin{array}{l}1.6192(4) \\
1.6185\end{array}$ & $\begin{array}{l}0.4289(2) \\
0.4292\end{array}$ & $\begin{array}{l}\text { This work } \\
\text { [26] }\end{array}$ \\
\hline $\mathrm{Ho}_{11} \mathrm{Sn}_{10}$ & $I 4 / \mathrm{mmm}$ & $\mathrm{Ho}_{11} \mathrm{Ge}_{10}$ & $\begin{array}{l}1.1518(6) \\
1.152\end{array}$ & $\begin{array}{l}- \\
-\end{array}$ & $\begin{array}{l}1.6777(7) \\
1.680\end{array}$ & $\begin{array}{l}\text { This work } \\
\text { [27] }\end{array}$ \\
\hline $\mathrm{Ho}_{5} \mathrm{Sn}_{3}$ & $\mathrm{PG}_{3} / \mathrm{mcm}$ & $\mathrm{Mn}_{5} \mathrm{Si}_{3}$ & $\begin{array}{l}0.8845(2) \\
0.8847\end{array}$ & $\begin{array}{l}- \\
-\end{array}$ & $\begin{array}{l}0.6452(3) \\
0.6458\end{array}$ & $\begin{array}{l}\text { This work } \\
\text { [28] }\end{array}$ \\
\hline $\mathrm{Ho}_{14} \mathrm{Ag}_{51}$ & $P 6 / m$ & $\mathrm{Gd}_{14} \mathrm{Ag}_{51}$ & $\begin{array}{l}1.2589(6) \\
1.2609\end{array}$ & $\begin{array}{l}- \\
-\end{array}$ & $\begin{array}{l}0.9241(5) \\
0.9257\end{array}$ & $\begin{array}{l}\text { This work } \\
\text { [29] }\end{array}$ \\
\hline $\mathrm{HoAg}_{2}$ & $I 4 / \mathrm{mmm}$ & $\mathrm{MoSi}_{2}$ & $\begin{array}{l}0.3674(3) \\
0.3681\end{array}$ & $\begin{array}{l}- \\
-\end{array}$ & $\begin{array}{l}0.9179(4) \\
0.9181\end{array}$ & $\begin{array}{l}\text { This work } \\
\text { [30] }\end{array}$ \\
\hline HoAg & $P m-3 m$ & $\mathrm{CsCl}$ & $\begin{array}{l}0.3587(3) \\
0.3601\end{array}$ & $\begin{array}{l}- \\
-\end{array}$ & $\begin{array}{l}- \\
-\end{array}$ & $\begin{array}{l}\text { This work } \\
\text { [31] }\end{array}$ \\
\hline $\mathrm{TmSn}_{2}$ & $\mathrm{Cmcm}$ & $\mathrm{ZrSi}_{2}$ & $\begin{array}{l}0.4349(4) \\
0.4357\end{array}$ & $\begin{array}{l}1.6053(7) \\
1.6062\end{array}$ & $\begin{array}{l}0.4276(4) \\
0.4285\end{array}$ & $\begin{array}{l}\text { This work } \\
\text { [26] }\end{array}$ \\
\hline $\mathrm{Tm}_{11} \mathrm{Sn}_{10}$ & $I 4 / \mathrm{mmm}$ & $\mathrm{Ho}_{11} \mathrm{Ge}_{10}$ & $\begin{array}{l}1.1389(8) \\
1.142\end{array}$ & $\begin{array}{l}- \\
-\end{array}$ & $\begin{array}{l}1.6667(7) \\
1.668\end{array}$ & $\begin{array}{l}\text { This work } \\
\text { [27] }\end{array}$ \\
\hline $\mathrm{Tm}_{5} \mathrm{Sn}_{3}$ & $\mathrm{PG}_{3} / \mathrm{mcm}$ & $\mathrm{Mn}_{5} \mathrm{Si}_{3}$ & $\begin{array}{l}0.8767(4) \\
0.8733\end{array}$ & $\begin{array}{l}- \\
-\end{array}$ & $\begin{array}{l}0.6403(3) \\
0.6406\end{array}$ & $\begin{array}{l}\text { This work } \\
\text { [28] }\end{array}$ \\
\hline $\mathrm{Tm}_{14} \mathrm{Ag}_{51}$ & $P 6 / m$ & $\mathrm{Gd}_{14} \mathrm{Ag}_{51}$ & $1.2477(6)$ & - & $0.9179(5)$ & This work \\
\hline $\operatorname{TmAg}_{3}$ & Pmmn & $\mathrm{Cu}_{3} \mathrm{Ti}$ & $\begin{array}{l}0.4944(4) \\
0.4948\end{array}$ & $\begin{array}{l}0.6071(5) \\
0.6075\end{array}$ & $\begin{array}{l}0.5159(4) \\
0.5163\end{array}$ & $\begin{array}{l}\text { This work } \\
\text { [29] }\end{array}$ \\
\hline $\mathrm{TmAg}_{2}$ & $I 4 / \mathrm{mmm}$ & $\mathrm{MoSi}_{2}$ & $\begin{array}{l}0.3653(2) \\
0.3650\end{array}$ & $\begin{array}{l}- \\
-\end{array}$ & $\begin{array}{l}0.9138(4) \\
0.9129\end{array}$ & $\begin{array}{l}\text { This work } \\
\text { [32] }\end{array}$ \\
\hline $\operatorname{TmAg}$ & $P m-3 m$ & $\mathrm{CsCl}$ & $\begin{array}{l}0.3541(2) \\
0.3543\end{array}$ & $\begin{array}{l}- \\
-\end{array}$ & $\begin{array}{l}- \\
-\end{array}$ & $\begin{array}{l}\text { This work } \\
\text { [33] }\end{array}$ \\
\hline $\mathrm{Ag}_{0.8-x} \mathrm{Sn}_{0.2+x}$ & $\mathrm{P6}_{3} / m m c$ & $\mathrm{Mg}$ & $\begin{array}{l}0.2956(1)- \\
0.2983(2) \\
0.29285\end{array}$ & $\begin{array}{l}- \\
- \\
-\end{array}$ & $\begin{array}{l}0.4752(2)- \\
0.4750(2) \\
0.47853\end{array}$ & $\begin{array}{l}\text { This work } \\
\text { [34] }\end{array}$ \\
\hline $\mathrm{Ag}_{3} \mathrm{Sn}$ & Pmmn & $\mathrm{Cu}_{3} \mathrm{Ti}$ & $\begin{array}{l}0.4774(4) \\
0.4780\end{array}$ & $\begin{array}{l}0.5964(3) \\
0.5968\end{array}$ & $\begin{array}{l}0.5181(5) \\
0.5184\end{array}$ & $\begin{array}{l}\text { This work } \\
{[35]}\end{array}$ \\
\hline
\end{tabular}


L. Romaka et al., Formation and stability of ternary phases in the Ho-Ag-Sn and Tm-Ag-Sn metallic systems

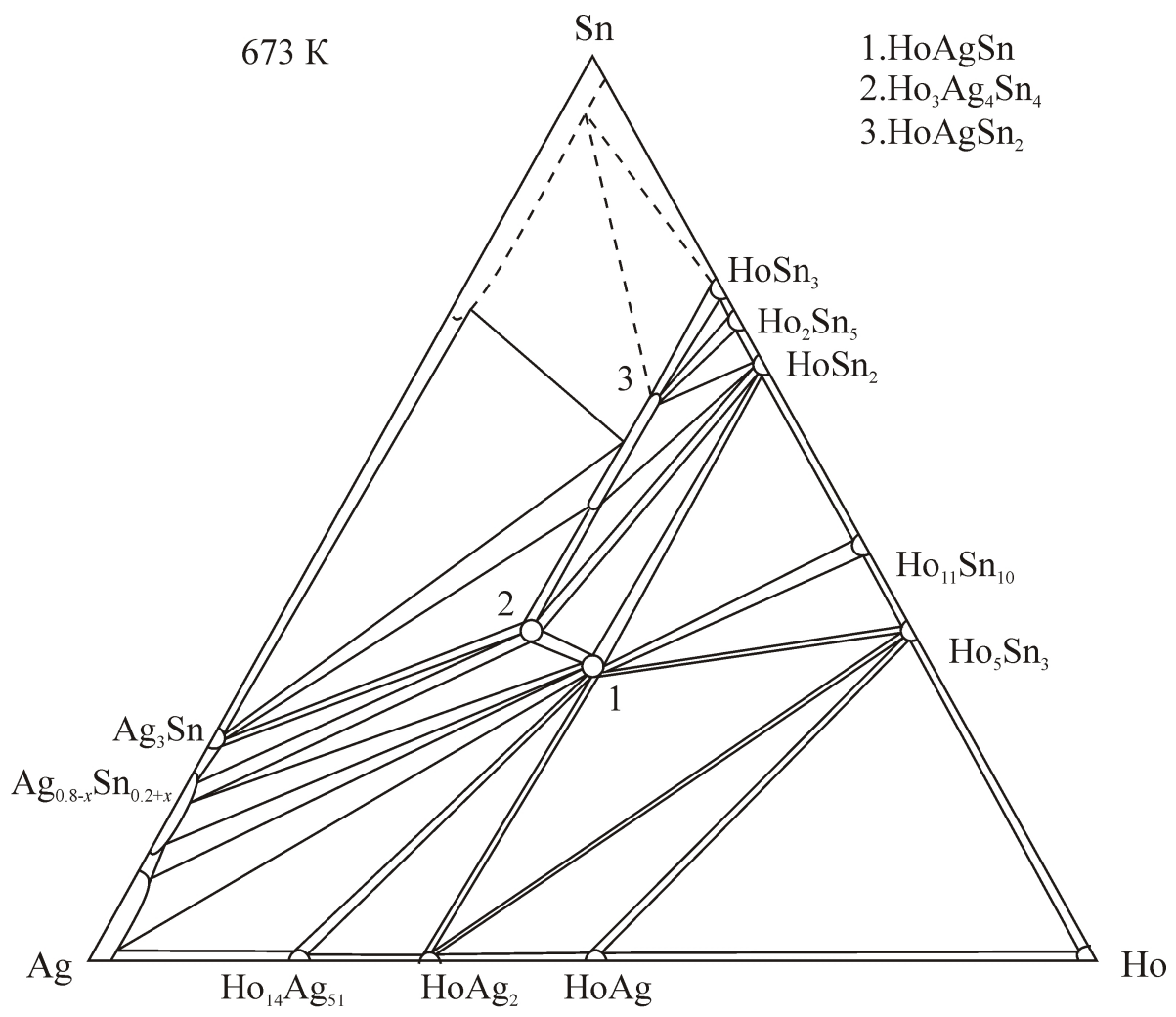

Fig. 1 Isothermal section of the Ho-Ag-Sn system at $673 \mathrm{~K}$.

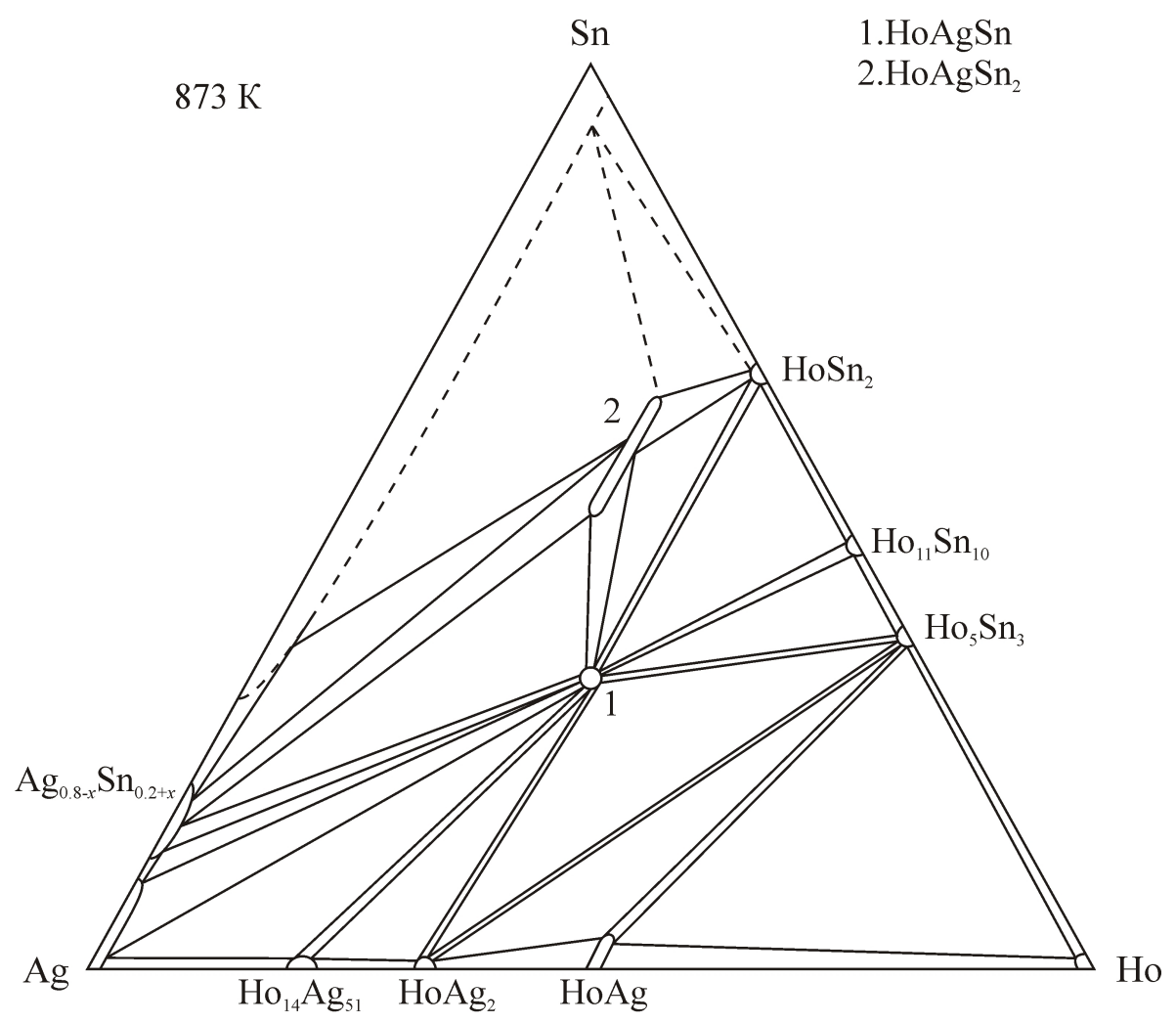

Fig. 2 Isothermal section of the Ho-Ag-Sn system at $873 \mathrm{~K}$. 

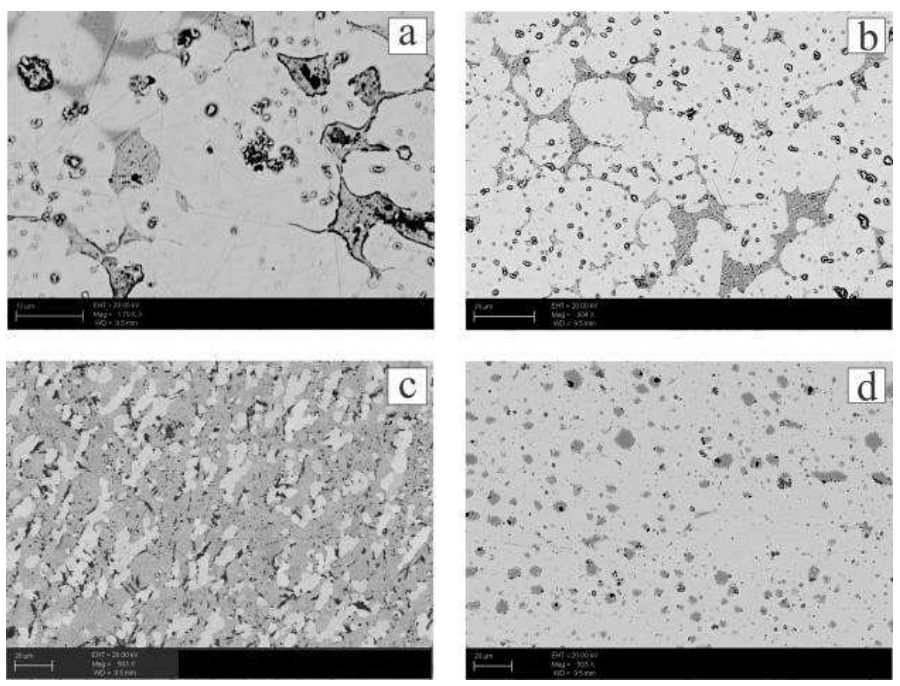

Fig. 3 Electron microphotographs of the alloys:

a) $\mathrm{Ho}_{25} \mathrm{Ag}_{10} \mathrm{Sn}_{65}(673 \mathrm{~K})-\mathrm{HoAgSn}_{2}\left(\mathrm{Ho}_{24.99} \mathrm{Ag}_{12.20} \mathrm{Sn}_{62.81}\right.$, light grey phase), $\mathrm{Ag}_{3} \mathrm{Sn}$ (dark grey phase), $\mathrm{Sn}$ (grey phase);

b) $\mathrm{Ho}_{25} \mathrm{Ag}_{10} \mathrm{Sn}_{65}(873 \mathrm{~K})-\mathrm{HoAgSn}_{2}\left(\mathrm{Ho}_{25.28} \mathrm{Ag}_{11.07} \mathrm{Sn}_{63.65}\right.$, light grey phase), $\mathrm{Ag}_{4} \mathrm{Sn}$ (dark grey phase), Sn (grey phase);

c) $\mathrm{Ho}_{25} \mathrm{Ag}_{30} \mathrm{Sn}_{45}(673 \mathrm{~K})-\mathrm{HoAgSn}_{2}\left(\mathrm{Ho}_{25.82} \mathrm{Ag}_{23.63} \mathrm{Sn}_{50.55}\right.$, light grey phase), HoAgSn (white phase), $\mathrm{Ho}_{3} \mathrm{Ag}_{4} \mathrm{Sn}_{4}$ (dark phase);

d) $\mathrm{Ho}_{24} \mathrm{Ag}_{24} \mathrm{Sn}_{52}(873 \mathrm{~K})-\mathrm{HoAgSn}\left(\mathrm{Ho}_{25.64} \mathrm{Ag}_{20.99} \mathrm{Sn}_{53.37}\right.$, light grey phase), $\mathrm{Ag}_{4} \mathrm{Sn}$ (grey phase).

Table 2 Crystallographic data of the ternary compounds in the Ho-Ag-Sn system.

\begin{tabular}{c|l|l|l|l|l|l}
\hline \multirow{2}{*}{ No. } & \multicolumn{1}{|c|}{ Compound } & \multirow{2}{*}{ Structure type } & \multirow{2}{*}{ Space group } & \multicolumn{3}{|c}{ Unit cell parameters, $\mathrm{nm}$} \\
\cline { 5 - 7 } & & & \multicolumn{2}{c}{$a$} & \multicolumn{1}{c}{$c$} \\
\hline 1 & $\mathrm{HoAgSn}$ & $\mathrm{LiGaGe}_{2}$ & $P 6_{3} m c$ & $0.4667(1)$ & - & $0.7313(2)$ \\
2 & $\mathrm{Ho}_{3} \mathrm{Ag}_{4} \mathrm{Sn}_{4}{ }^{\mathrm{a}}$ & $\mathrm{Gd}_{3} \mathrm{Cu}_{4} \mathrm{Ge}_{4}$ & Immm & $0.4519(2)$ & $0.7280(3)$ & $1.5091(3)$ \\
3 & $\mathrm{HoAgSn}_{2}$ & $\mathrm{Cu}_{3} \mathrm{Au}$ & $P m-3 m$ & $0.4525(2)$ & - & \\
\hline
\end{tabular}

The compound number corresponds to the number in the phase diagrams (Fig. 1).

${ }^{a}$ at $673 \mathrm{~K}$

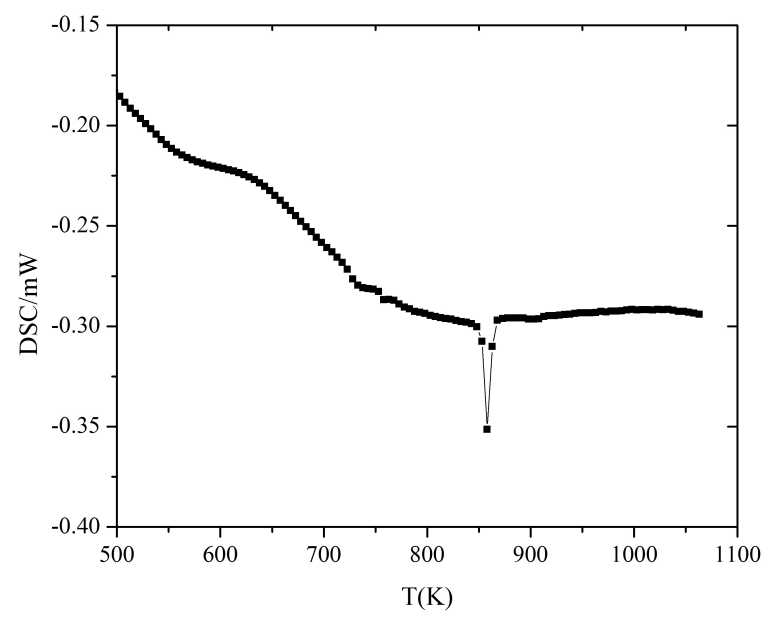

Fig. 4 DSC curve for the $\mathrm{Ho}_{3} \mathrm{Ag}_{4} \mathrm{Sn}_{4}$ compound.

\subsection{Isothermal section of the Tm-Ag-Sn system} The annealing temperature for the Tm-Ag-Sn system was chosen based on literature data concerning the TmAgSn compound (low-temperature modification at $970 \mathrm{~K})$, and the low melting temperature of Sn. The phase diagram of the $\mathrm{Tm}-\mathrm{Ag}-\mathrm{Sn}$ system was consequently investigated at $873 \mathrm{~K}$, using X-ray diffraction and EMP analyses of 8 binary and 35 ternary alloys (Fig. 5). SEM pictures of some of the alloys are shown in Fig. 6. The existence of the earlier known TmAgSn compound with $\mathrm{ZrNiAl}$ structure type [10] was confirmed at $873 \mathrm{~K}$. From the results of the XRD and EPM analyses of samples in the Sn-rich part of the Tm-Ag-Sn system, a new ternary compound of composition $\mathrm{Tm}_{25} \mathrm{Ag}_{25} \mathrm{Sn}_{50}$ was found. The analysis of the diffraction patterns of alloys along the isoconcentrate of 25 at. $\% \mathrm{Tm}$ indicated a small homogeneity region $\left(\mathrm{Tm}_{25} \mathrm{Ag}_{25} \mathrm{Sn}_{50}-\mathrm{Tm}_{25} \mathrm{Ag}_{20} \mathrm{Sn}_{55}\right.$, $a=0.45033(2)-0.4522(1) \mathrm{nm})$ of the $\mathrm{TmAgSn}_{2}$ 
compound. The limiting composition of the $\mathrm{TmAgSn}_{2}$ compound was confirmed by the electron microprobe analysis $\left(\mathrm{Tm}_{26.27} \mathrm{Ag}_{19.18} \mathrm{Sn}_{54.55}\right)$. The sample at higher Sn content, $\mathrm{Tm}_{23} \mathrm{Ag}_{18} \mathrm{Sn}_{59}$ (Fig. 6d), is located in a three-phase region and contains the $\mathrm{TmAgSn}_{2}$ compound in equilibrium with the $\mathrm{TmSn}_{2}$ and $\mathrm{Sn}$ phases. The $\mathrm{Tm}_{33} \mathrm{Ag}_{22} \mathrm{Sn}_{45}$ sample contains the main phase $\mathrm{TmAgSn}_{2}$, and in addition $\mathrm{TmAgSn}$ and $\mathrm{TmSn}_{2}$ (Fig. 6c).

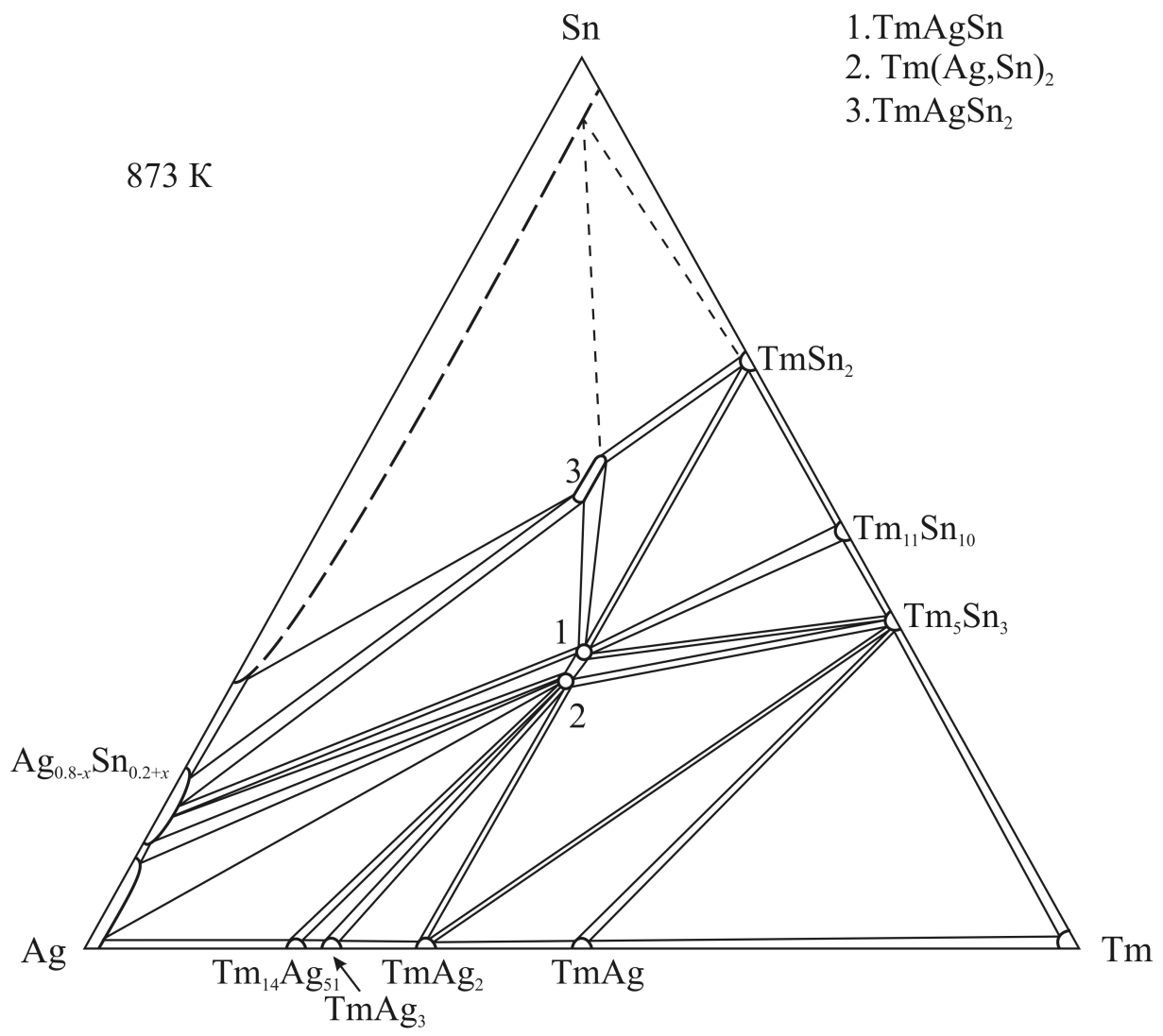

Fig. 5 Isothermal section of the $\mathrm{Tm}-\mathrm{Ag}-\mathrm{Sn}$ system at $873 \mathrm{~K}$.
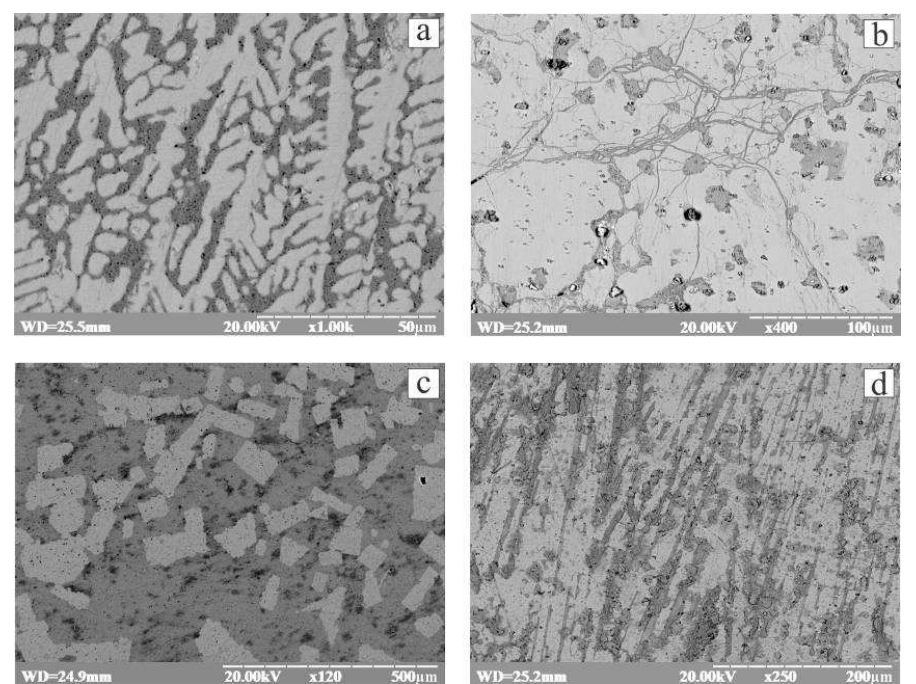

Fig. 6 Electron microphotographs of the alloys:

a) $\mathrm{Tm}_{20} \mathrm{Ag}_{60} \mathrm{Sn}_{20}-\mathrm{Tm}(\mathrm{Ag}, \mathrm{Sn})_{2}\left(\mathrm{Tm}_{33.3} \mathrm{Ag}_{38.20} \mathrm{Sn}_{28.5}\right.$, grey phase), Ag (dark grey phase);

b) $\mathrm{Tm}_{30} \mathrm{Ag}_{36} \mathrm{Sn}_{34}-\mathrm{TmAgSn}\left(\mathrm{Tm}_{32.77} \mathrm{Ag}_{34.25} \mathrm{Sn}_{32.96}\right.$, light grey phase), $\mathrm{Ag}_{0.8} \mathrm{Sn}_{0.2}$ (dark grey phase), $\mathrm{TmAgSn}_{2}$ (grey phase);

c) $\mathrm{Tm}_{33} \mathrm{Ag}_{22} \mathrm{Sn}_{45}$ - TmAgSn $\left(\mathrm{Tm}_{32.89} \mathrm{Ag}_{33.02} \mathrm{Sn}_{34.09}\right.$, light grey phase), $\mathrm{TmAgSn}\left(\mathrm{Tm}_{24.39} \mathrm{Ag}_{49.87} \mathrm{Sn}_{25.74}\right)$, grey phase), $\mathrm{TmSn}_{2}$ (dark grey phase);

d) $\mathrm{Tm}_{23} \mathrm{Ag}_{18} \mathrm{Sn}_{59}-\mathrm{TmAgSn}_{2}\left(\mathrm{Tm}_{26.27} \mathrm{Ag}_{19.18} \mathrm{Sn}_{54.55}\right.$, light grey phase), $\mathrm{TmSn}_{2}$ (grey phase), Sn (dark grey phase). 
As mentioned above, the TmAgSn stannide is characterized by the existence of two polymorphic modifications with ZrNiAl-type (low-temperature modification) and LiGaGe-type (high-temperature modification) structures [16]. We confirmed the existence of the TmAgSn stannide with the $\mathrm{ZrNiAl}$ type at the stoichiometry 1:1:1 at $873 \mathrm{~K}$. Nevertheless, the phase analysis of samples in the Ag-rich part of the $\mathrm{Tm}-\mathrm{Ag}-\mathrm{Sn}$ system clearly indicated the presence of a ternary phase of the CaIn ${ }_{2}$-type (disordered variant of the ternary LiGaGe-type) at 33 at.\% Tm and a lower concentration of Sn ( 30 at.\% Sn). Fig. 6a shows the presence of large grains of the $\operatorname{Tm}(\mathrm{Ag}, \mathrm{Sn})_{2}$ phase, which is in equilibrium with silver. The XRD analysis of samples between TmAgSn (ZrNiAl-type) and $\mathrm{Tm}(\mathrm{Ag}, \mathrm{Sn})_{2}\left(\mathrm{CaIn}_{2}\right.$-type $)$ indicates that the two phases are in equilibrium. To check the influence of temperature on the stability of the TmAgSn compound different annealing temperatures were used. The XRD analysis of the studied sample indicates the presence of the TmAgSn phase in the as-cast sample and after annealing at $670 \mathrm{~K}, 770 \mathrm{~K}$ (LiGaGe-type), and $1270 \mathrm{~K}$ (CaIn 2 -type). The sample annealed at $870 \mathrm{~K}$ and $1070 \mathrm{~K}$ contains the TmAgSn phase with $\mathrm{ZrNiAl}-$ type. The TmAgSn compound was examined by differential thermal analysis and the results confirmed the limited temperature range for the modification with the $\mathrm{ZrNiAl}$ structure type. The DTA curve measured in the heating regime shows two thermal peaks at $795 \mathrm{~K}$ and $1196 \mathrm{~K}$ (Fig. 7), which can be associated with the formation of the ZrNiAl-type structure and its further polymorphic transformation into the $\mathrm{CaIn}_{2}$-type, respectively.

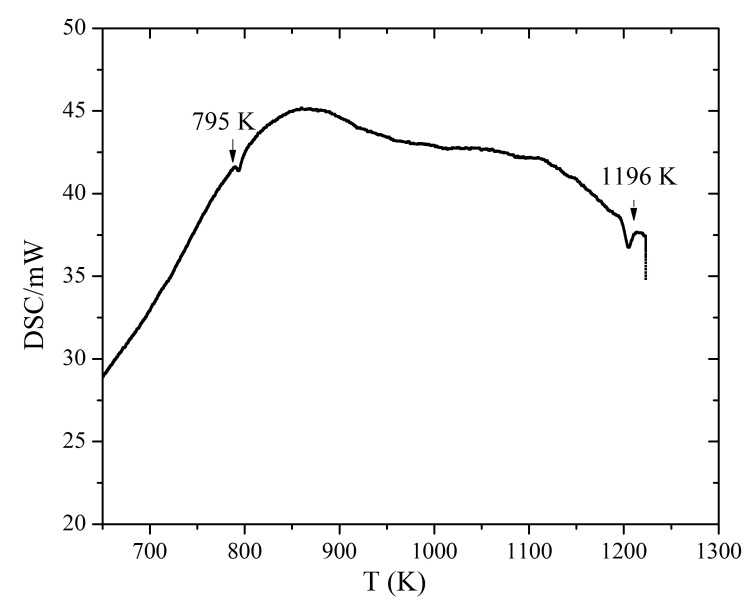

Fig. 7 DTA curve for the TmAgSn compound.

Magnetic susceptibility measurements performed on the TmAgSn sample (annealed at $770 \mathrm{~K}$, LiGaGe-type) indicated Curie-Weiss paramagnetic behavior in the temperature range 80-350 K (Fig. 8). The calculated effective magnetic moment is close to $\mathrm{Tm}^{3+}$ ion value $\left(\mu_{\mathrm{eff}}=7.62(3) \mu_{\mathrm{B}}\right)$.
The crystallographic characteristics of the Tm-Ag-Sn ternary compounds are listed in Table 3. Solubility of the third component in the binary phases was not observed under the present conditions.

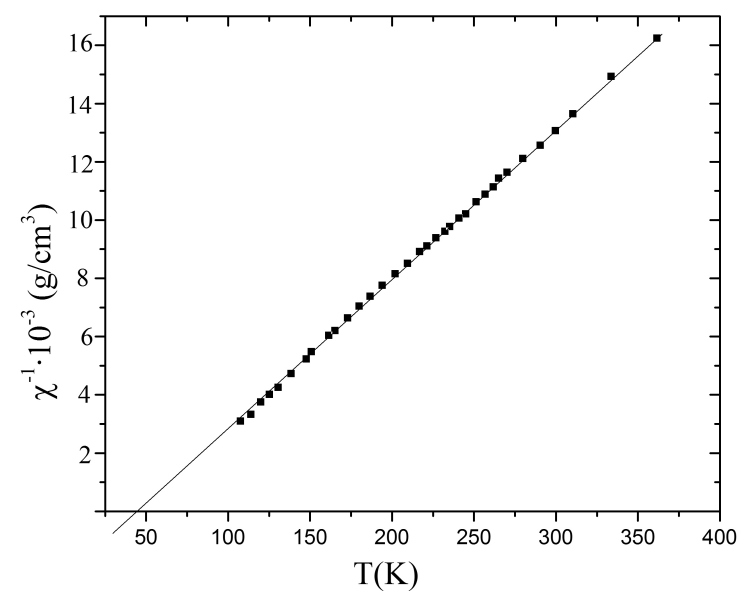

Fig. 8 Temperature dependence of the magnetic susceptibility for the TmAgSn compound (LiGaGe-type).

\subsection{Crystal structures}

The crystal structure of the new $\mathrm{TmAgSn}_{2}$ compound was determined using $\mathrm{X}$-ray powder diffraction. The powder pattern of the $\mathrm{Tm}_{25} \mathrm{Ag}_{25} \mathrm{Sn}_{50}$ sample was indexed on the basis of a cubic lattice with the cell parameter $a=0.45033(2) \mathrm{nm}$, and indicated that this compound belongs to the $\mathrm{Cu}_{3} \mathrm{Au}$ type (space group $\mathrm{Pm}-3 \mathrm{~m}$ ). The $\mathrm{Ag} / \mathrm{Sn}$ ratio in $3 c$ position was fixed at the value $0.333 / 0.667$ corresponding to the stoichiometry of the sample and the EPMA data. The atomic coordinates and displacement parameters are listed in Table $4 \quad\left(R_{\text {Bragg }}=0.023, \quad R_{\mathrm{p}}=0.059\right.$, $\left.R_{\mathrm{wp}}=0.093\right)$. The observed, calculated and difference $\mathrm{X}$-ray patterns of the $\mathrm{Tm}_{25} \mathrm{Ag}_{25} \mathrm{Sn}_{50}$ sample are shown in Fig. 9. The atomic environment of the thulium atoms is a cuboctahedron of composition $(\mathrm{Ag}, \mathrm{Sn})_{12}$ and that of the $(\mathrm{Ag}, \mathrm{Sn})$ atoms is a cuboctahedron $(\mathrm{Ag}, \mathrm{Sn})_{8} \mathrm{Tm}_{4}$ (interatomic distances are $0.3184 \mathrm{~nm})$.

A detailed crystal structure investigation performed on the $\mathrm{Tm}_{20} \mathrm{Ag}_{60} \mathrm{Sn}_{20}$ sample confirmed that it belongs to the $\mathrm{CaIn}_{2}$ structure type (space group $\left.P 6_{3} / m m c, \quad a=0.46534(2), \quad c=0.72649(4) \mathrm{nm}\right)$ with statistical distribution of $\mathrm{Ag}$ and $\mathrm{Sn}$ atoms in the $4 f$ atomic position. The (Ag,Sn) mixture in $4 f$ position corresponds to the formula $\mathrm{TmAg}_{1.14} \mathrm{Sn}_{0.86}$, which is in a good agreement with the EPMA data (Fig. 6a). The final atomic parameters, refined to $R_{\mathrm{p}}=0.0532, R_{\mathrm{wp}}=0.073, R_{\mathrm{Bragg}}=0.0317$ are listed in Table 5. The observed, calculated, and difference $\mathrm{X}$-ray patterns of the $\mathrm{Tm}_{20} \mathrm{Ag}_{60} \mathrm{Sn}_{20}$ sample are presented in Fig. 10. The Tm-Sn and $\mathrm{Tm}-\mathrm{Ag}(\mathrm{Sn})$ interatomic distances are $0.3632 \mathrm{~nm}$ and $0.3067 \mathrm{~nm}$, respectively. 
L. Romaka et al., Formation and stability of ternary phases in the Ho-Ag-Sn and $\mathrm{Tm}-\mathrm{Ag}-\mathrm{Sn}$ metallic systems

Table 3 Crystallographic data of the ternary compounds in $\mathrm{Tm}-\mathrm{Ag}-\mathrm{Sn}$ system.

\begin{tabular}{c|l|l|l|l|l|l}
\hline \multirow{2}{*}{ No. } & \multicolumn{1}{|c|}{ Compound } & \multirow{2}{*}{ Structure type } & \multicolumn{2}{|c|}{ Space group } & \multicolumn{3}{|c}{ Unit cell parameters, $\mathrm{nm}$} \\
\cline { 5 - 7 } & & & $a$ & \multicolumn{1}{c}{$c$} \\
\hline 1 & $\mathrm{TmAgSn}$ & $\mathrm{ZrNiAl}$ & $P-62 m$ & $0.72635(9)$ & - & $0.4435(1)$ \\
2 & $\mathrm{Tm}\left(\mathrm{Ag}, \mathrm{Sn}_{2}\right.$ & $\mathrm{CaIn}_{2}$ & $P 6_{3} / m m c$ & $0.46534(2)$ & - & $0.72649(4)$ \\
3 & $\left(\mathrm{TmAg}_{1.14} \mathrm{Sn}_{0.86}\right)$ & $\mathrm{Tu}_{3} \mathrm{Au}$ & $P m-3 m$ & $0.45033(2)$ & - & - \\
\hline
\end{tabular}

The compound number corresponds to the number in the phase diagrams (Fig. 5).

Table 4 Final atomic parameters of the $\mathrm{TmAgSn}_{2}$ compound.

\begin{tabular}{c|c|c|c|c|c}
\hline Atom & $\begin{array}{c}\text { Wyckoff } \\
\text { position }\end{array}$ & $x / a$ & $y / b$ & $z / c$ & $B_{\text {iso }} 10^{2} \mathrm{~nm}^{2}$ \\
\hline$T m$ & $1 a$ & 0 & 0 & 0 & $1.02(6)$ \\
$M^{\mathrm{a}}$ & $3 c$ & 0 & $1 / 2$ & $1 / 2$ & $1.34(3)$ \\
\hline
\end{tabular}

${ }^{\mathrm{a}} M=0.333 \mathrm{Ag}+0.667 \mathrm{Sn}$.

Table 5 Final atomic parameters of the $\mathrm{Tm}(\mathrm{Ag}, \mathrm{Sn})_{2}$ compound.

\begin{tabular}{c|c|c|c|c|c}
\hline Atom & $\begin{array}{c}\text { Wyckoff } \\
\text { Position }\end{array}$ & $x / a$ & $y / b$ & $z / c$ & $B_{\text {iso }} 10^{2} \mathrm{~nm}^{2}$ \\
\hline $\mathrm{Tm}$ & $2 b$ & 0 & 0 & $1 / 4$ & $0.55(5)$ \\
$M^{\mathrm{a}}$ & $4 f$ & $1 / 3$ & $2 / 3$ & $0.0462(1)$ & $0.64(6)$ \\
\hline
\end{tabular}

${ }^{\mathrm{a}} M=0.572(2) \mathrm{Ag}+0.428(1) \mathrm{Sn}$.

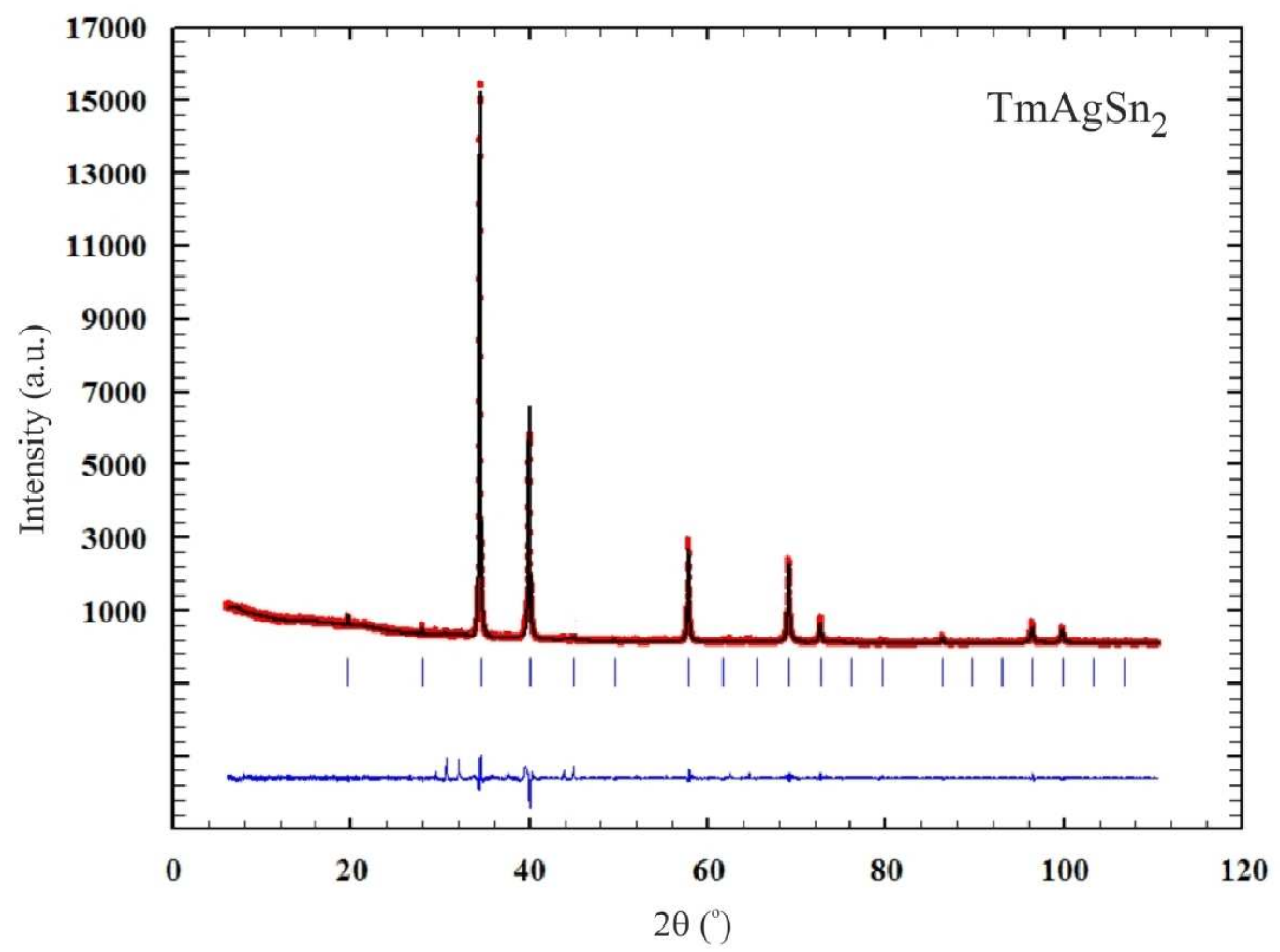

Fig. 9 Observed, calculated and difference X-ray patterns of the $\operatorname{TmAgSn}_{2}$ compound. 


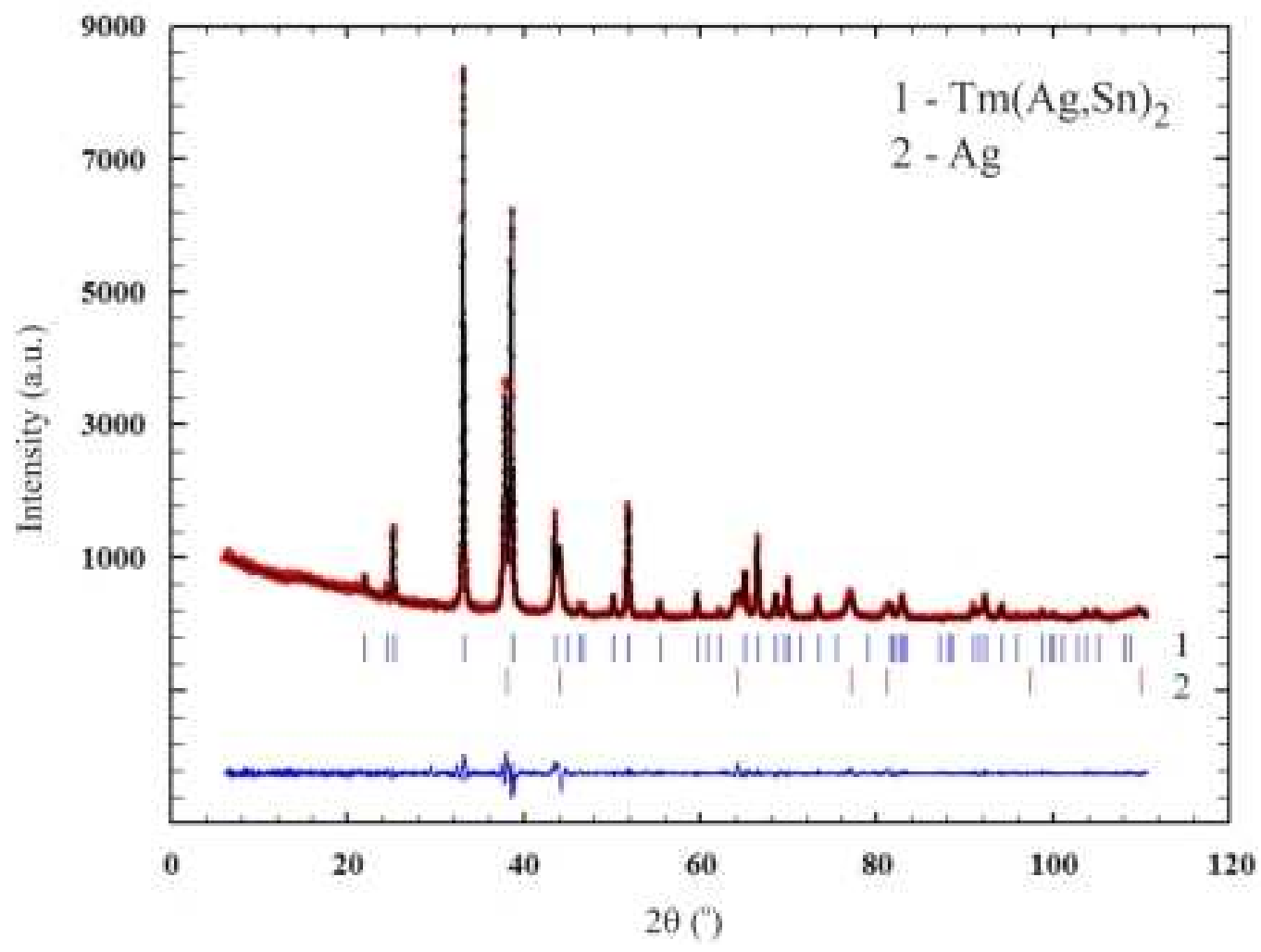

Fig. 10 Observed, calculated and difference X-ray patterns of the $\operatorname{Tm}(\mathrm{Ag}, \mathrm{Sn})_{2}$ compound.

\subsection{DFT calculations}

In the $\mathrm{HoAgSn}_{2}$ structure the $3 c$ site is filled by a statistical mixture of $\mathrm{Ag}$ and $\mathrm{Sn}$. In order to simulate such a mixture the symmetry was reduced to $P 1$. The distribution of the density of states of $\mathrm{HoAgSn}_{2}$ (Fig. 11a) showed that the valence band is mainly formed by filled $\mathrm{Ag} d$-states and partially filled $f$-states of Ho. These states are highly localized in the DOS spectra, while the $s$ - and $p$-states of $\mathrm{Sn}$ are mostly delocalized. The overlap of bands of $\mathrm{Ag}$ and $\mathrm{Sn}$ is weak. The analysis of the charge density distribution in the crystal revealed excess between $\mathrm{Ag}$ and $\mathrm{Sn}$ atoms, while for the Ho atoms the distribution was close to spherical. Such a distribution is common for polar intermetallics with covalently bonded $\mathrm{Ag}$ and $\mathrm{Sn}$ atoms that form a negatively charged sublattice due to additional electrons transferred from Ho atoms.

The electronic structure of $\mathrm{Ho}_{3} \mathrm{Ag}_{4} \mathrm{Sn}_{4}$ was calculated using the following number of atoms in the unit cell: $2 \times \mathrm{Ho} 1,1 \times \mathrm{Ho} 2,4 \times \mathrm{Ag}, 2 \times \mathrm{Sn} 1,2 \times \mathrm{Sn} 2$. In contrast to $\mathrm{HoAgSn}_{2}$ the distribution of the density of states in $\mathrm{Ho}_{3} \mathrm{Ag}_{4} \mathrm{Sn}_{4}$ (Fig. 11b) is "noisier". The valence band is mainly formed by $\mathrm{Ag} d$-states, $\mathrm{Sn}$ $s$ - and $p$-states and partially filled $f$-states of Ho. The bonding situation is rather strange, as $\mathrm{HoAgSn}_{2}$ contains more $\mathrm{Sn}$ atoms than $\mathrm{Ho}_{3} \mathrm{Ag}_{4} \mathrm{Sn}_{4}$, which play a major role in the formation of the covalent bonds. The distribution of the electron localization function in $\mathrm{Ho}_{3} \mathrm{Ag}_{4} \mathrm{Sn}_{4}$ shows localization between $\mathrm{Sn} 2$ atoms (Fig. 12). Taking into account that the Sn2-Sn2 distance $(0.28914 \mathrm{~nm})$ is close to the sum of the $\mathrm{Sn}$ covalent radii $\left(r_{\text {cov }}=0.141 \mathrm{~nm}\right)$ such ELF localization makes sense and confirms the covalent character of the Sn2-Sn2 bonding. This conclusion agrees with the short Sn2-Sn2 distances $(0.278-0.283 \mathrm{~nm})$ and their covalent character in isotypic $R_{3} \mathrm{Cu}_{4} \mathrm{Sn}_{4}$ compounds ( $R=\mathrm{Tb}, \mathrm{Dy}, \mathrm{Tm})[36,37]$.

Both $\mathrm{HoAgSn}_{2}$ and $\mathrm{Ho}_{3} \mathrm{Ag}_{4} \mathrm{Sn}_{4}$ are predicted to have metallic type of conductivity, due to the absence of a band gap at the Fermi level. In the case of the $\mathrm{HoAgSn}_{2}$ compound the calculations confirmed a previous experimental study of the electrical properties [38].

\section{Final remarks}

With regard to the previous results of the studied compounds formed by a heavy rare earth, silver and tin and our results it worth noting the importance of the temperature/pressure on the formation, stability and structure of the intermediate phases in $R-\mathrm{Ag}-\mathrm{Sn}$ systems.

The main feature of the $R-\mathrm{Ag}-\mathrm{Sn}$ systems with a heavy rare earth is the formation of $R \mathrm{AgSn}_{2}$ ternary phases of the cubic $\mathrm{Cu}_{3} \mathrm{Au}$-type as, a result of the stabilization of the high-pressure cubic $R \mathrm{Sn}_{3}$ binaries $\left(\mathrm{Cu}_{3} \mathrm{Au}\right.$-type) [39] in the ternary region. However, in the $R-\mathrm{Ag}-\mathrm{Sn}$ systems with a light rare earth, where the binary compounds $R \mathrm{Sn}_{3}$ crystallize in the cubic 

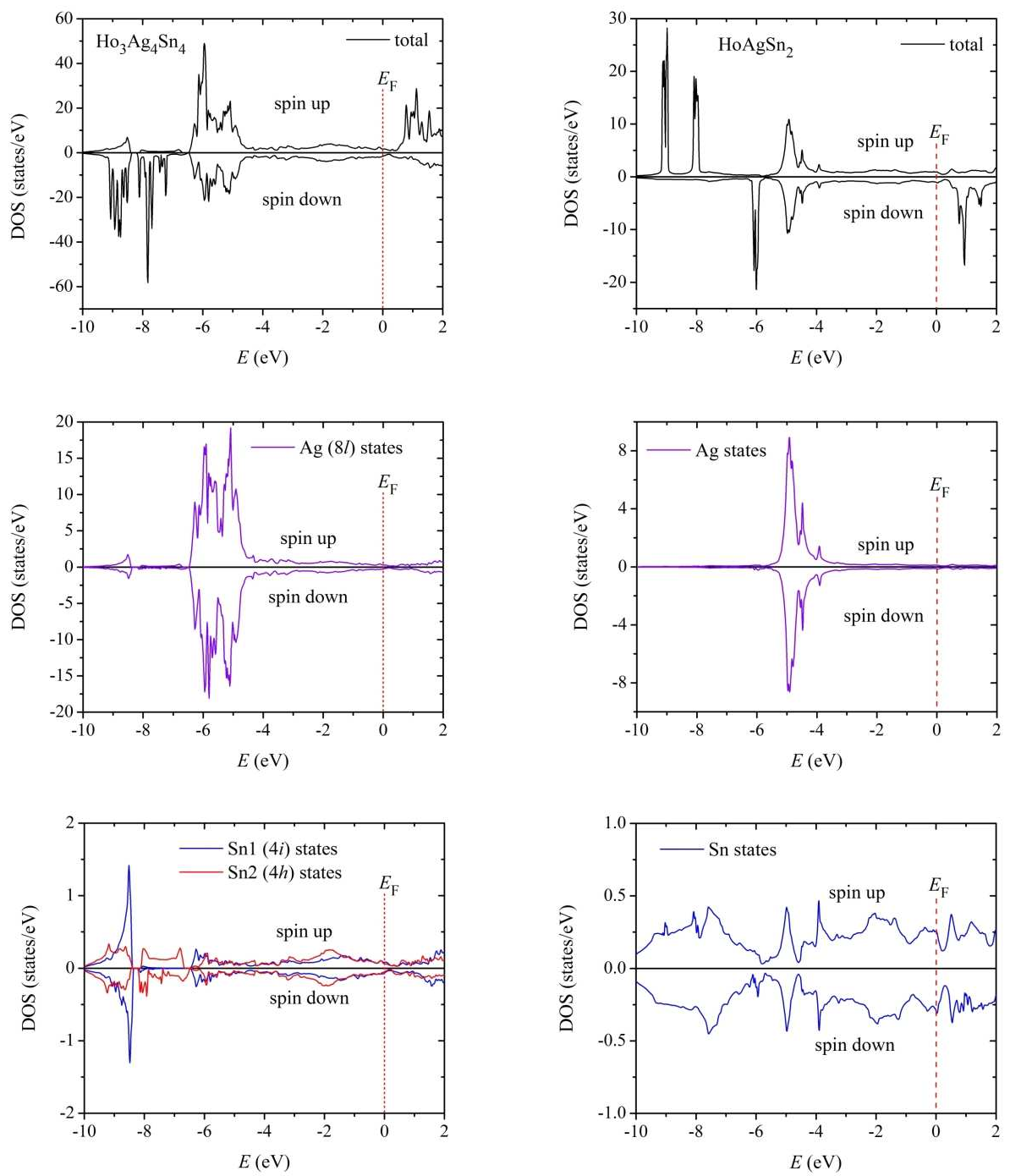

a

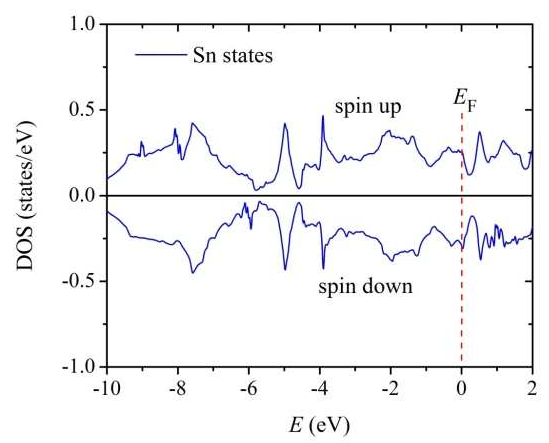

$\mathrm{b}$

Fig. 11 Distribution of the total and partial (without interstitial atoms, Fermi level at $E=0 \mathrm{eV}$ ) density of states (DOS) of $\mathrm{Ho}_{3} \mathrm{Ag}_{4} \mathrm{Sn}_{4}$ (a) and $\mathrm{HoAgSn}_{2}$ (b).

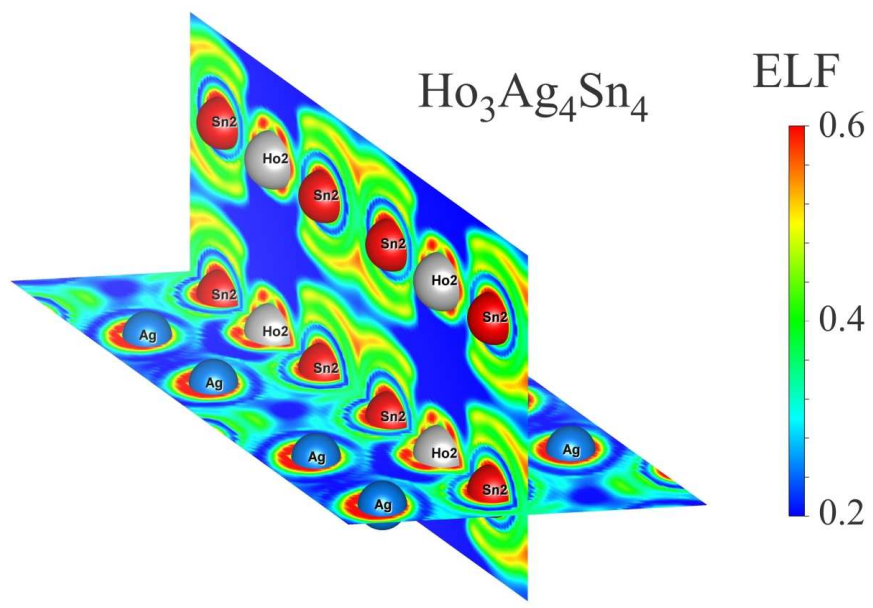

Fig. 12 The distribution of the electron localization function (ELF) in $\mathrm{Ho}_{3} \mathrm{Ag}_{4} \mathrm{Sn}_{4}$. 
$\mathrm{Cu}_{3} \mathrm{Au}$-type, extended solid solutions based on the $R \mathrm{Sn}_{3}$ compounds are observed [1-3,5]. In the case of the $\mathrm{Gd}-\mathrm{Ag}-\mathrm{Sn}$ system the replacement of $\mathrm{Sn}$ atoms by $\mathrm{Ag}$ along the isoconcentrate of 25 at.\% Gd strongly depends on the temperature due to the presence of two polymorphic modifications of the $\mathrm{GdSn}_{3}$ binary ( $\mathrm{GdSn}_{2.75^{-}}$and $\mathrm{Cu}_{3} \mathrm{Au}$-types) [17].

A larger temperature range (from $\sim 800 \mathrm{~K}$ to $\sim 1200 \mathrm{~K}$ ) of existence of TmAgSn crystallizing in the ZrNiAl-type is observed in comparison to [16]. The structure of both polymorphic modifications of TmAgSn ( $\mathrm{ZrNiAl}$ and $\mathrm{CaIn}_{2} / \mathrm{LiGaGe}$ structure types) are characterized by trigonal prismatic coordination of the smaller atom (AgTm6). In the case of ordered TmAgSn of LiGaGe-type the structure could be presented as stacking columns of octahedra TmSn6 with $\mathrm{Ag}$ atoms in tetrahedra (AgSn4) (Fig. 13). Both structures of TmAgSn have similarity in stacking of the AgTm6 trigonal prisms which form the hexagonal channels (Fig. 14).

\section{TmAgSn (LiGaGe-type)}

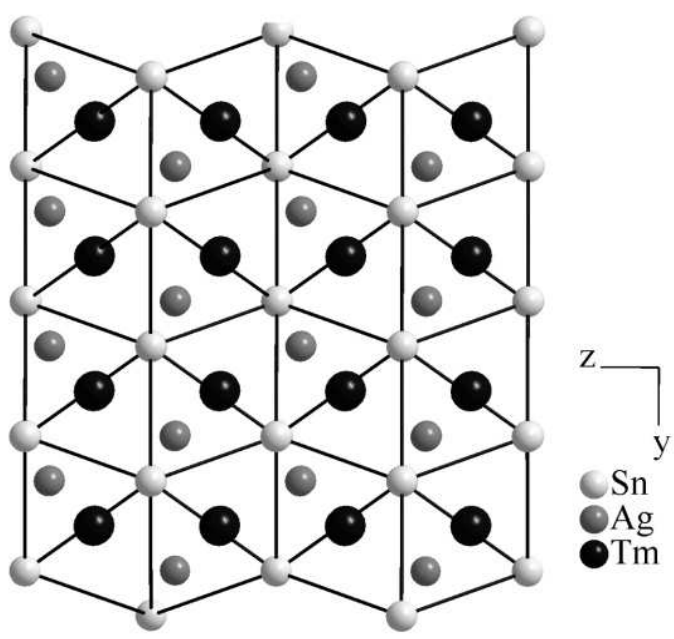

Fig. 13 Packing of octahedra around Tm atoms and tetrahedra around $\mathrm{Ag}$ atoms in $\mathrm{TmAgSn}$ (LiGaGe-type).

\section{References}

[1] J. Liang, C. Liao, Y. Du, Y. Tang, Y. Han, Y. He, S. Liu, J. Alloys Compd. 493 (2010) 122-127.

[2] P. Boulet, D. Mazzone, N. Noël, P. Riani, P. Rogl, R. Ferro, Intermetallics 7 (1999) 931935.

[3] D. Mazzone, P, Riani, G. Zanicchi, R. Marazza, R. Ferro, Intermetallics 10 (2002) 801-809.

[4] P. Salamakha, O. Zaplatynsky, O. Sologub, O. Bodak, J. Alloys Compd. 239 (1996) 94-97.

[5] I. Romaniv, L. Romaka, V.V. Romaka, Yu. Stadnyk, Visn. Lviv. Univ., Ser. Khim. 55 (2014) 1-3.

[6] Z. Hossain, R. Nagarajan, M. Etile, C. Godart, J.P. Kappler, L.C. Gupta, R.Vijayaraghavan, J. Magn Magn Mater. 150 (1995) 223-226.

[7] V.V. Romaka, V. Davydov, R. Gladyshevskii, N. Melnychenko, J. Alloys Compd. 443 (2007) 68-70.

[8] V.V. Romaka, V. Davydov, L. Romaka, Yu. Stadnyk, J. Alloys Compd. 457 (2008) 329-331.

[9] G. Zanicchi, D. Mazzone, P. Riani, R. Marazza, R. Ferro, J. Alloys Compd. 317-318 (2001) 513-520.

[10] C.P. Sebastian, H. Eckert, C. Fehse, J.P. Wright, J.P. Attfield, D. Johrendt, S. Rayaprol, R.D. Hoffman, R. Pöttgen, J. Solid State Chem. 179 (2006) 2376-2385.

[11] S. Baran, J. Leciejewicz, N. Stuesser, A. Szytuła, A. Zygmunt, R.Y. Ding, J. Magn. Magn. Mater. 170 (1997) 143-154.

[12] R. Pöttgen, P.E. Arpe, C. Felser, D. Kußmann, R. Müllmann, B.D. Mosel, B. Künnen, G. Kotzyba, J. Solid State Chem. 145 (1999) 668-677.

[13] D. Mazzone, D. Rossi, R. Marazza, R. Ferro, J. Less-Common Met. 80 (1981) 47-52.

[14] B. Heying, U.C. Rodewald, G. Heymann, W. Hermes, F.M. Schappacher, J.F. Riecken, C.P. Sebastian, H. Huppertz, R. Pöttgen, Z. Naturforsch. B 63(2) (2008) 193-198.

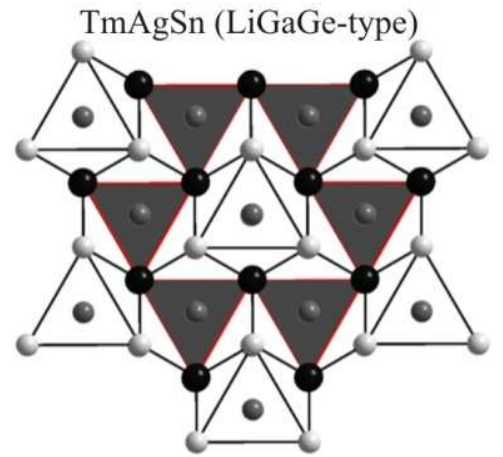

a

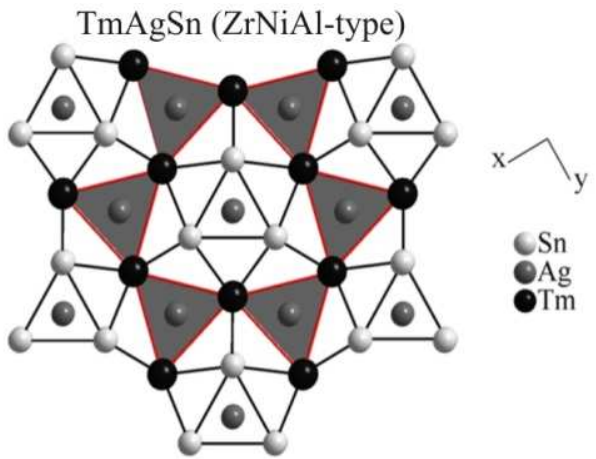

b

Fig. 14 Stacking of AgTm6 trigonal prisms in the TmAgSn structure with LiGaGe (a) and $\mathrm{ZrNiAl}$ (b) types. 
[15] W. Bazela, J. Leciejewicz, K. Maletka, A. Szytuła, J. Magn. Magn. Mater. 117 (1992) L1-L4.

[16] C.P. Sebastian, G. Heymann, B. Heying, U.C. Rodewald, H. Huppertz, Z. Anorg. Allgem. Chem. 633(10) (2007) 1551-1555.

[17] I. Lototska, V. Romaka, L. Romaka, Yu. Stadnyk, Visn. Lviv. Univ., Ser. Khim. 53 (2012) 20-27.

[18] L. Akselrud, Yu. Grin, J. Appl. Crystallogr. 47 (2014) 803-805.

[19] T. Roisnel, J. Rodriguez-Carvajal, Mater. Sci. Forum 378-381 (2001) 118-123.

[20] ELK, Program package; http://elk.sourceforge.net/

[21] J.P. Perdew, K. Burke, M. Ernzerhof, Phys. Rev. Lett. 77 (1996) 3865-3868.

[22] K. Momma, F. Izumi, J. Appl. Crystallogr. 41 (2008) 653-658.

[23] T.B. Massalski, In: Binary Alloy Phase Diagrams, ASM, Metals Park, Ohio (1990).

[24] P. Villars, L.D. Calvert (Eds.), Pearson's Handbook of Crystallographic Data for Intermetallic Phases, ASM, Metals Park, Ohio, 1991.

[25] A. Palenzona, P. Manfrinetti, J. Alloys Compd. 201 (1993) 43-47.

[26] A. Iandelli, A. Palenzona, G.B. Bonino, Atti Accad. Naz. Lincei, Cl. Sci. Fis., Mat. Nat., Rend. 40 (1966) 623-628.
[27] M.L. Fornasini, F. Merlo, G.B. Bonino, Atti Accad. Naz. Lincei, Cl. Sci. Fis., Mat. Nat., Rend. 50 (1971) 186-196.

[28] W. Jeitschko, E. Parthé, Acta Crystallogr. 22 (1967) 551-555.

[29] O.D. McMasters, K.A. Gschneidner Jr., R.F. Venteicher, Acta Crystallogr. B 26 (1970) 1224-1229.

[30] P. Morin, J.A. Blanco, J. Magn. Magn. Mater. 119 (1993) 59-68.

[31] T. Kaneko, S. Ohta, S. Abe, H. Yoshida, M. Ohashi, J. Magn. Magn. Mater. 90/91 (1990) 583-584.

[32] A. Iandelli, A.P. Palenzona, J. Less-Common Met. 15 (1968) 272-284.

[33] P. Morin, D. Schmitt, J. Magn. Magn. Mater. 28 (1982) 188-192.

[34] M. Nuding, M. Ellner, J. Alloys Compd. 252 (1997) 184-191.

[35] C.W. Fairhurst, J.B. Cohen, Acta Crystallogr. B 28 (1972) 371-378.

[36] V. Romaka, V. Pavlyuk, B. Marciniak, A. Tkachuk, Pol. J. Chem. 82 (2008) 2049-2055.

[37] L. Romaka, V.V. Romaka, V. Davydov, Chem. Met. Alloys 1(2) (2008) 192-197.

[38] L. Romaka, V.V. Romaka, I. Lototska, A. Szytuła, B. Kuzhel, A. Zarzycki, E.K. Hlil, D. Fruchart, Bull. Mater. Sci. 36(7) (2013) 1247-1253.

[39] K. Miller, H.T. Hall, Inorg. Chem. 11 (1972) 1188-1191. 